\title{
KOMUNIKASI BISNIS BERBASIS ETIKA LINGKUNGAN SEBAGAI CSR THE BODY SHOP INDONESIA (Studi Kasus: Kampanye \#Pay4Plastic)
}

\author{
Yunike Hardhiyanti \\ Ilmu Komunikasi, Universitas Bunda Mulia \\ Alamat surel: nikee.hardhiyan@gmail.com \\ Udung Noor Rasyid \\ Magister Ilmu Komunikasi, Universitas Bunda Mulia \\ Alamat surel: Udungnoor@yahoo.co.id
}

\begin{abstract}
This study entitled "Environmental Ethics-Based Business Communication Corporate Social Responsibility as a Form of The Body Shop Indonesia (Case Study: Campaign \# Pay4Plastik The Body Shop Indonesia in Jakarta). This study aims to: 1). Knowing how The Body Shop conduct ethical business communications on its corporate activities in the sphere of corporate internal and external; 2). Knowing why The Body Shop is very focused on the issues and CSR activities related to the environment one of them \# Pay4Plastic; 3). Knowing how The Body Shop see CSR \# Pay4Plastic it does generate a positive impact in society. The method used is a case study. In this case the techniques of data collection is done through observation, interviews, and documentation. The results of this study: 1). The Body Shop conduct their business communications internally and externally corporation using the communication channels it uses. The communication channel is used to convey the principle of business being operated are: product communications strategy, public relations, as well as the corners are in the Head Office of The Body Shop Indonesia is used as a depiction of the type of business carried on by The Body Shop Indonesia in particular. 2). The Body Shop will focus on the things that are socially and environmentally because the goal of The Body Shop is a cosmetic brand in the world's most ethical and sustainable global business truth. In addition, The Body Shop is a pioneer of CSR as well as the first global business practices fair trade and conduct social and environmental campaigns. CSR The Body Shop Indonesia via Campaign \# Pay4Plastic also associated with it, where the campaign carried out in addition to building public awareness of plastic waste. The campaign also used as business communication to create employees and consumers loyalty. 3). The Body Shop see the positive impact generated from Campaign \#Pay4Plastic public through the many involved in the collection of plastic petitions paid. The Body Shop Indonesia also viewed in terms of the follow-up of the campaign \#Pay4Plastik been addressed by KLHK on December 30, 2015 will be a petition that has been collected by The Body Shop Indonesia offline. The results of the petition by the issuance of circulars under the Waste Management Office, Waste, Hazardous and Toxic Substances (No. SE-06 / PSLB3-PS / 2015) addressed to the heads of regions and businesses; regarding the implementation of paid plastic around the modern market outlets in Indonesia.
\end{abstract}

Keywords: Communication, Business, Ethics, CSR, Campaign

\begin{abstract}
Abstrak
Penelitian ini berjudul "Komunikasi Bisnis Berbasis Etika Lingkungan Sebagai Bentuk Corporate Social Responsibility The Body Shop Indonesia (Studi Kasus: Kampanye \#Pay4Plastik The Body Shop Indonesia Di Jakarta. Penelitian ini betujuan untuk: 1). Mengetahui bagaimana The Body Shop melakukan komunikasi bisnis beretika pada kegiatan korporasinya dalam lingkup internal \& eksternal korporasi ; 2). Mengetahui mengapa The Body Shop sangat fokus pada isu-isu serta kegiatan CSR yang terkait dengan lingkungan salah satunya \#Pay4Plastic; 3). Mengetahui bagaimana The Body Shop melihat CSR \#Pay4Plastic yang dilakukannya menghasilkan dampak positif di masyarakat. Metode penelitian yang digunakan adalah studi kasus. Dalam hal ini teknik pengumpulan data dilakukan melalui observasi, wawancara, dan studi dokumentasi. Hasil Penelitian ini, yaitu: 1). The Body Shop melakukan komunikasi bisnisnya secara lingkup internal \& eksternal korporasi dengan menggunakan kanal-kanal komunikasi yang digunakannya. Adapun kanal komunikasi yang digunakan untuk menyampaikan prinsip bisnis yang
\end{abstract}

Jurnal Bricolage Vol. 3 No. 2 
dijalankannya adalah: Strategi komunikasi produk, Public Relations, serta sudut-sudut yang berada di Head Office The Body Shop Indonesia yang dijadikan sebagai penggambaran jenis bisnis yang dijalankan oleh The Body Shop Indonesia khususnya. 2). The Body Shop fokus akan hal-hal yang bersifat sosial dan lingkungan dikarenakan tujuan The Body Shop adalah sebagai brand kosmetik yang paling beretika di dunia dan bisnis global berkelanjutan yang sebenarnya. Selain itu, The Body Shop merupakan pelopor CSR serta bisnis global pertama yang mempraktikkan perdagangan yang adil serta melakukan kampanye sosial dan lingkungan. CSR yang dilakukan The Body Shop Indonesia melalui Kampanye \#Pay4Plastic juga terkait dengan hal tersebut, dimana kampanye yang dilakukan selain untuk membangun kesadaran masyarakat akan sampah plastik. Kampanye tersebut juga digunakan sebagai komunikasi bisnis untuk menciptakan para karyawan dan konsumen yang loyalitas. 3). The Body Shop melihat dampak positif yang ditimbulkan dari Kampanye \#Pay4Plastic ini melalui banyaknya publik yang ikut terlibat dalam pengumpulan petisi plastik berbayar. The Body Shop Indonesia juga melihat dari sisi tindak lanjut dari kampanye \#Pay4Plastik yang telah ditanggapi oleh Kementerian Lingkungan Hidup dan Kehutanan (KLHK) Republik Indonesia pada tanggal 30 Desember 2015 akan petisi yang telah dikumpulkan oleh The Body Shop Indonesia secara offline. Hasil dari petisi tersebut dengan dikeluarkannya surat edaran di bawah Dirjen Pengelolaan Sampah, Limbah, dan Bahan Beracun Berbahaya (Nomor: SE-06/PSLB3PS/2015) yang ditujukan kepada kepala daerah dan pelaku usaha; mengenai penerapan plastik berbayar di seluruh gerai pasar modern di Indonesia.

Kata Kunci: Komunikasi, Bisnis, Etika, CSR, Kampanye

\section{PENDAHULUAN}

Bisnis merupakan suatu kegiatan yang sudah dijalankan sejak ratusan tahun lalu. Berbagai jenis bisnis yang ada hingga saat ini juga sangat beragam seiring dengan perkembangan jaman. Apabila kita lihat lingkup bisnis tidak harus terkait dengan produk, namun penyediaan jasa pun bisa dikategorikan sebagai bisnis. Bisnis yang akan diangkat pada jurnal ini adalah mengenai sebuah bisnis yang dijalankan oleh The Body Shop yang merupakan salah satu produk kosmetik ternama.

Walaupun The Body Shop telah diakuisisi oleh L'Oréal pada tahun 2006, namun nilai-nilai perusahaan yang dipegang oleh The Body Shop masih sama sejak mereka berdiri, yaitu:

1. Against Animal Testing

2. Support Community Trade

3. Activate Self Esteem

4. Defend Human Rights

5. Protect Our Planet

Pada usianya yang ke-40 tahun, The Body Shop International secara global meluncurkan komitmen terbarunya untuk meneguhkan values yang selama ini dipegangnya. Menurut website resmi The Body Shop Indonesia (www.thebodyshop.co.id) adapun komitmen tersebut diberi nama Enrich Not Exploit (It's in Our Hands) yang terdiri dari:

\section{Enrich Our People \\ 2. Enrich Our Product \\ 3. Enrich Our Planet}

Berdasarkan nilai-nilai perusahaan tersebut The Body Shop bisa menjalankan komunikasi bisnis yang berbeda dengan yang lainnya. Menjadi berbeda daripada yang lain dalam hal etika dalam berbisnis merupakan keunikan serta menjadi daya tarik peneliti untuk meneliti mengenai komunikasi bisnis berbasis etika yang telah dijalankan oleh The Body Shop. Walaupun The Body Shop menjalankan gaya berbisnis seperti itu, namun untuk pencapaian profit serta pembukaan store di berbagai wilayah tetap berjalan dengan baik. Namun dengan keunikan yang dimiliki oleh The Body Shop, kegiatan bisnisnya masih dapat memberikan hal positif tidak hanya bagi konsumen, namun juga bagi masyarakat melalui kegiatan dan kampanye yang dilakukannya.

Adapun salah satu kegiatan The Body Shop yang tekun digeluti beberapa tahun belakangan ini, serta sedang ramai disuarakan adalah mengenai ajakan pengurangan penggunaan kantong plastik yang bekerja sama dengan salah satu organisasi lingkungan non profit, yaitu Gerakan Indonesia Diet Kantong Plastik 
(GIDKP) melalui kampanye yang digalakkan \#Pay4Plastic. Diet kantong plastik dipilih menjadi salah satu topik kampanye yang didukung dikarenakan menurut sumber berita www.cnnindonesia.com yang diunduh pada tanggal 23 Februari 2016, menyatakan bahwa Indonesia merupakan negara penyumbang sampah plastik terbesar di dunia kedua setelah China.

Kerjasama yang dijalin oleh The Body Shop dengan GIDKP menurut Rika Anggraini (General Manager of Corporate Communication The Body Shop) dalam salah satu artikel menyatakan bahwa kerjasama yang dibangun oleh organisasi tersebut sudah dijalankan sejak lama dan hal tersebut adalah bagian dari Corporate Social Responsibility (CSR) mereka.

Bisnis dan komunikasi adalah dua hal yang tidak dapat terpisahkan, bagaikan dua mata uang yang saling berhubungan. Adapun tujuan dari bisnis dan komunikasi adalah agar tercapainya kepentingan dan pengertian bersama. Sedangkan tujuan CSR adalah keberlangsungan perusahaan itu sendiri, dan hal tersebut adalah penting dilakukan bagi semua perusahaan tanpa terkecuali guna memberikan manfaat positif secara internal maupun eksternal perusahaan.

\section{TINJAUAN PUSTAKA}

\section{Komunikasi Bisnis}

Menurut Katz (1994:4) komunikasi bisnis adalah adanya pertukaran ide, pesan, dan konsep yang berkaitan dengan pencapaian serangkaian tujuan komersil. Komunikasi bisnis diartikan sebagai komunikasi yang terjadi dalam dunia bisnis dalam rangka mencapai tujuan dari bisnis itu. Oleh karena itu istilah bisnis dalam konteks ini diterjemahkan sebagai suatu organisasi perusahaan.

Menurut Poerwanto (2012:57-58) komunikasi bisnis adalah proses interaksi antara pemangku kepentingan dalam pertukaran informasi dan pesan yang berkaitan dengan proses produksi dan pemasaran. Pemangku kepentingan yang dimaksud dalam komunikasi bisnis adalah produsen, pelanggan, distributor, dan masyarakat. Definisi di atas menunjukkan bahwa bisnis merupakan sebuah komunitas. Dijelaskan kembali oleh Purwanto (2006:4) komunikasi bisnis adalah komunikasi yang digunakan dalam dunia bisnis yang mencakup berbagai macam bentuk komunikasi, baik komunikasi verbal maupun komunikasi nonverbal untuk mencapai tujuan tertentu.

\section{Model Etika dalam Bisnis}

Menurut Carrol dan Buchollz (2005) dalam Ma'ruf (2015:59-62) dilihat dari tingkatan manajemen cara pelaku bisnis menerapkan etika bisnis dapat digolongkan menjadi tiga, masing-masing:

1. Immoral Manajemen

Merupakan tingkatan terendah dari model manajemen dalam menerapkan prinsip-prinsip etika bisnis. Manajer yang memiliki manajemen tipe ini pada umumnya sama sekali tidak mengindahkan apa yang dimaksud dengan moralitas, baik dalam internal organisasinya maupun bagaimana dia menjalankan aktivitas bisnisnya (Rudito dan Famiola, 2013:303-304).

2. Amoral Manajemen

Tingkatan kedua dalam aplikasi etika dan moralitas manajemen adalah Amoral manajemen. Berbeda dengan Immoral manajemen, manajer dengan tipe manajemen seperti ini bukan tidak tahu sama sekali dengan etika atau moralitas. Ada dua jenis manajemen tipe amoral ini, yaitu: a). Manajer yang dikenal tidak sengaja berbuat amoral (unintentional amoral manager), b). Manajer yang sengaja berbuat amoral.

3. Moral Manajemen

Tingkatan tertinggi dari penerapan nilai-nilai etika atau moralitas dalam bisnis adalah moral manajemen. Dalam moral manajemen nilai-nilai etika dan moralitas diletakkan pada level standar tertinggi dari segala bentuk perilaku dan aktivitas bisnisnya. Manajer yang masuk tipe 
ini tidak hanya menerima dan mematuhi aturan-aturan yang berlaku, namun juga telah terbiasa meletakan prinsip-prinsip etika dalam kepemimpinannya. Manajer yang masuk dalam tipe ini sebagaimana juga manajer lain tentu saja juga menginginkan keuntungan dalam bisnisnya. Namun baginya keuntungan tersebut harus didapatkan secara legal, dan juga tidak melanggar etika yang berlaku dalam masyarakat, seperti: keadilan, kejujuran dan semangat untuk mematuhi hukum yang berlaku.

\section{Corporate Sosial Responsibility (CSR)}

Menurut ISO 26000 dalam Nindita (2014:9) yang merupakan standar panduan tanggung jawab sosial (Standard Guidance for Sosial Responsibility) bahwa ruang lingkup CSR mencakup hulu ke hilir, harus diutamakan untuk pemangku kepentingan di dalam perusahaan, dan CSR merupakan bagian dari investasi bisnis, sehingga melalui CSR yang benar, perusahaan dapat meningkatkan harga saham. Melalui CSR perusahaan dapat menciptakan nilai, meningkatkan kebahagiaan (well being), dan dapat menciptakan perubahan yang inovatif.

Menurut Castka (2004) dalam Nindita terdapat dua ranah pengertian CSR, yakni ranah filosofis dan ranah pragmatis. Secara filosofis, CSR berasal dari teori etika. Terdapat tiga ranah etika, yakni secara teleology adalah berkaitan dengan konsekuensi (Utilitarianisme); menurut deontology adalah berhubungan dengan tugas (duty-based); dan berdasarkan virtue adalah menjaga keseimbangan (virtuebased). Jadi, melakukan CSR berarti cara perusahaan menciptakan bisnis yang dapat memberikan kebaikan untuk orang banyak. Sedangkan dalam ranah pragmatis, CSR merupakan aktivitas holistik terintegrasi yang dapat dimasukkan sebagai bagian dari sistem manajemen.

Persoalan utama yang dihadapi perusahaan adalah bagaimana menghubungkan antara ranah filosofis dengan pragmatis tersebut. Biasanya ranah filosofis berhubungan dengan perumusan filosofi perusahaan.

\section{Jenis Perubahan CSR}

Nindita (2014:39-40) menyatakan bahwa terdapat tiga jenis perubahan berkat tanggung jawab sosial, yakni emergent change (perubahan yang muncul), transformative change (perubahan transformatif), dan projectable change (perubahan yang diprediksi). Perubahan emergent terjadi dalam kegiatan sehari-hari yang membuat pelaku bisnis harus selalu beradaptasi secara sadar. Misalnya, saat menghadapi karyawan yang berkonflik, perusahaan dapat mengubah peraturan dan budaya dengan mengajak karyawan saling menghormati perbedaan.

Jika pada emergent change ada proses belajar, pada perubahan transformatif justru terjadi proses tidak belajar, yang "membebaskan" perilaku berinovasi mewujudkan perubahan inovatif dan transformasional.

Biasanya ada dua pendekatan dalam melakukan perubahan, problem based approach dan creative approach. Pada pendekatan pertama, perusahaan mempersiapkan strategi alternatif berdasarkan prediksi (forecasting) persoalan yang dapat terjadi. Pendekatan kedua menekankan pada visioning, yakni membayangkan perubahan positif yang ingin diciptakan, kemudian "mundur" untuk merumuskan perencanaan guna mewujudkannya (backcasting) .

\section{Agen Perubahan Sosial}

CSR, perusahaan terbukti dapat menghasilkan perubahan sosial positif yang dapat memberikan kontribusi positif terhadap aspek ekonomi, sosial, dan lingkungan. Dengan kata lain, melalui investasi pada litbang, perusahaan telah menjadi agen perubahan sosial.

\section{Mengukur Dampak CSR}

Banyak perusahaan yang telah melakukan kegiatan tanggung jawab sosial atau CSR melaporkan kegiatan mereka melalui sustainability reporting dan iklan- 
iklan, tetapi tidak mengukur dampak kegiatan CSR tersebut. Banyak juga perusahaan yang sudah berusaha mengukur kinerja CSR, tetapi yang diukur adalah output-nya, bukan outcome-nya, yakni jumlah program mereka, bukan dampak kegiatan mereka. Pengukuran dampak sosial atas kegiatan CSR sangat penting guna memberikan manfaat keberlanjutan yang positif.

Istilah popular pengukuran ini adalah sosial impact assessment (SIA). Berikut ini beberapa patokan dalam Nindita (2014:151-154) yang dapat digunakan oleh perusahaan dalam mengukur dampak sosial kegiatan CSR-nya, yang dapat dibandingkan antara sebelum dan sesudah program CSR dijalankan.

1. Gaya Hidup

Bagaimana gaya hidup masyarakat penerima manfaat, bagaimana mereka bekerja, berbelanja, berinteraksi, dan bersosialisasi, serta melakukan rutinitas sehari-hari? Jika ternyata program CSR mengubah ke arah negatif, seperti yang dicontohkan di atas, maka harus diberi penyuluhan, misalnya tentang cara hidup hemat dan perencanaan perekonomian rumah tangga.

2. Budaya

Apakah nilai-nilai dan kepercayaan yang mereka anut? Apakah kebiasaan komunitas?

3. Komunitas, Kohesi Sosial

Adakah keeratan hubungan antara anggota komunitas, jasa-jasa komunitas yang sudah ada, karakter komunitas, dan stabilitas komunitas? Jangan sampai program CSR menciptakan jurang pemisah antara penerima manfaat yang berhasil dan yang tidak berhasil secara ekonomi.

4. Sistem Politik Komunitas

Bagaimana cara komunitas mengambil keputusan dalam memecahkan persoalan sosial di antara mereka? Siapa saja yang dianggap mempunyai pengaruh dalam pengambilan keputusan, dan mengapa mereka mempunyai pengaruh? Dengan pengembangan kewirausahaan komunitas, sistem demokrasi komunitas seharusnya dapat terpelihara, bahkan dipertahankan, karena pengambilan keputusan dilakukan bersama.

5. Kesejahteraan dan Kesehatan

Bagaimana tingkat dan ukuran kebahagiaan yang mereka anut sampai saat ini? Bagaimana kondisi fisik dan mental serta spiritual mereka, cara pemeliharaan kesehatan mereka, dan sebagainya? Program CSR sebaiknya meningkatkan kebahagiaan mereka dan menambah pengetahuan mereka tentang pemeliharaan kesehatan.

6. Rasa Aman dan Aspirasi

Bagaimana persepsi mereka akan rasa aman dan masa depan komunitas? Bagaimana aspirasi mereka atas komunitasnya dan masa dengan anak-anaknya? Program CSR yang baik adalah yang dapat menciptakan rasa aman, misalkan dengan memberikan penyuluhan untuk melindungi aset komunitas, baik berupa lingkungan maupun bisnis yang mereka kembangkan.

7. Hak Kekayaan Intelektual

Apakah mereka sudah memiliki kekayaan intelektual atas kearifan lokal yang dimiliki maupun dihasilkan oleh para individu dalam komunitas penerima manfaat? Program CSR sebaiknya dilakukan sampai memberikan bantuan pengurusan hak kekayaan intelektual, sehingga dapat melindungi hak cipta individu dan komunitas.

\section{Pengertian Kampanye}

Menurut Ruslan (2008:23) kampanye yang dikenal sejak 1940-an campaign is generally exemply persuasion in action atau dengan kata lain kampanye secara umum menampilkan suatu kegiatan yang bertitik tolak untuk membujuk. Sedangkan menurut Rogers dan Storey dalam Venus (2009:7) kampanye sebagai serangkaian tindakan komunikasi yang terencana dengan tujuan menciptakan efek 
tertentu pada sejumlah besar khalayak yang dilakukan secara berkelanjutan pada kurun waktu tertentu.

\section{Model Kampanye Ostergaard}

Menurut Ostergaard (2002:149) dalam Public Information Campaigns and Opinion Research mengatakan bahwa sebuah kampanye dimulai dengan adanya problem dan mencapai tujuan ketika problem tersebut berkurang atau terselesaikan. Ketika menganalisa sebuah problem, perlu diingat bahwa sebagian besar masalah sosial muncul dari banyak faktor sehingga dalam tahap pelaksanaan kampanye, konten kampanye harus dikonstruksi sedemikian rupa untuk dapat mempengaruhi aspek knowledge, attitude, dan skills dari publik sasaran. Ketiga aspek tersebut dapat membawa dampak pada terjadinya perubahan perilaku publik. Tahapan ini dituangkan dalam gambar model kampanye seperti berikut:

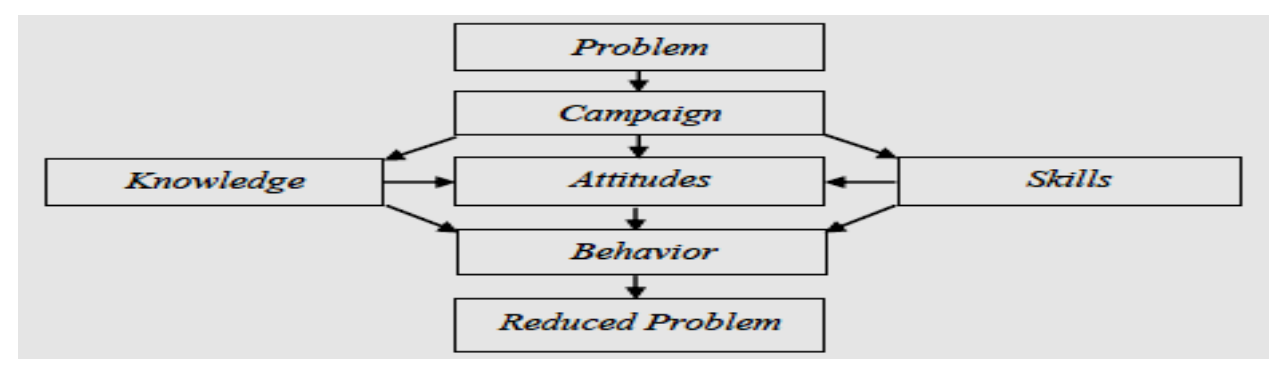

Sumber: Ostergaard (2002:149)

Gambar 1. Model Kampanye Ostergaard

\section{Komunikasi Lingkungan}

Seperti yang dikatakan oleh Oepen dan Winfried (1999:10) "Environmental Communication (EnvCom) is the planned and strategic use of communication processes and media products to support effective policy making, publik participation and project implementation geared towards environmental sustainability. Komunikasi lingkungan adalah perencanaan dan strategi yang digunakan dalam proses komunikasi dan media guna mendukung pembuat kebijakan, partisipasi publik dan implementasi proyek agar tercapainya keberlanjutan lingkungan. Komunikasi ini juga salah satu teknik yang digunakan dalam komunikasi pembangunan, sosial marketing, pertanian, public relations, dan pendidikan non formal. Dari strategi ini diharapkan adanya perubahan perilaku untuk mendukung terciptanya keberlanjutan lingkungan, seperti yang tergambar dibawah ini: 


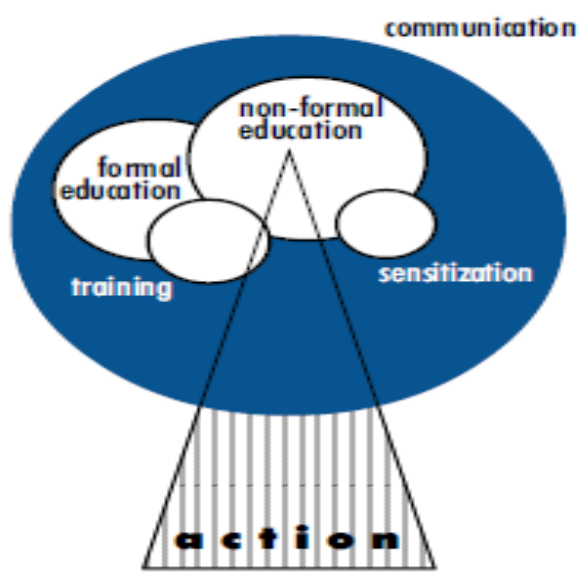

Sumber: Oepen dan Winfried (1999:10)

Gambar 2. Environmental Action Tree

\section{Elaboration Likelihood Theory (ELT)}

Sebuah tradisi sosiopsikologis dalam teori komunikasi (Littlejohn, 2009:97) mempunyai pengaruh yang sangat kuat pada bagaimana cara kita berpikir tentang pelaku komunikasi sebagai individu. Tujuan di balik tradisi ini adalah untuk memahami bagaimana dan mengapa setiap individu manusia berperilaku seperti yang mereka perbuat, sedangkan dalam komunikasi, ilmu pengetahuan dalam tradisi ini mencoba untuk menjawab pertanyaan, "Apa yang memperkirakan bagaimana pelaku komunikasi akan berpikir dan bertindak dalam kondisi seperti ini?". Kita akan melihat pada dua jenis teori dalam tradisi ini, yaitu teori sifat dan teori kognitif. Pada penelitian ini peneliti memilih dan memaparkan teori kognitif dari tradisi sosiopsikologis yang sesuai dengan kajian penelitian yang diangkat.

Teori kognisi dan pengolahan informasi menurut Littlejohn (2009:101) bekerja di belakang layar untuk menjelaskan bagaimana Anda berpikir, bagaimana Anda mengatur dan menyimpan informasi, serta bagaimana kognisi membantu membentuk perilaku Anda. Beberapa teori kesadaran yang sangat penting dalam literatur komunikasi; teori atribusi, teori penilaian sosial, dan teori penguraian kemungkinan. Teori-teori tersebut telah menjadi dasar untuk tradisi sosiopsikologis yang memberikan dasar untuk memahami bagaimana interpretasi dan persuasi terjadi di antara individu. Dalam penelitian ini, peneliti menggunakan Elaboration Likelihood Theory (ELT) sebagai teori penjelas mengenai kajian penelitian yang diteliti.

Richard Petty dan John Cacioppo (Littlejohn, 2009:108) merupakan psikolog sosial yang mengembangkan teori kemungkinan elaborasi (Elaboration Likelihood Theory - ELT) untuk membantu kita memahami semua perbedaan ini. ELT adalah sebuah teori persuasi karena teori ini mencoba untuk memprediksi kapan serta bagaimana Anda akan dan tidak akan terbujuk oleh pesan. Teori kemungkinan elaborasi mencoba untuk menjelaskan dengan cara yang berbeda di mana Anda mengevaluasi informasi yang Anda terima.

Elaboration Likelihood Theory (ELT) merupakan teori yang dikembangkan oleh John Cacioppo dan Richard E. Petty (Littlejohn dan Foss, 2009:330) yang menggambarkan bahwa terdapat dua jalur dalam proses komunikasi persuasif. Teori ini menggambarkan bagaimana individu akan mengevaluasi informasi yang diterimanya secara kritis ataupun tidak yang akan dijelaskan dalam dua jalur yang berbeda, yaitu jalur utama dan jalur pinggiran. Adapun efek yang ditimbulkan dari cara memproses informasi melalui dua jalur ini juga berbeda, jalur utama lebih cenderung untuk menghasilkan suatu perubahan 
perilaku secara tetap, sedangkan jalur pinggiran lebih cenderung untuk menghasilkan suatu perubahan perilaku secara temporer.

\section{- Jalur Utama}

Littlejohn dan Foss (2009:331) menjelaskan bahwa pada jalur ini individu yang menerima informasi akan mengolahnya secara kritis terhadap pesan persuasif yang diterimanya. Ketika individu tersebut menerima informasi yang berkaitan dengan kehidupannya, maka proses pengolahan informasi yang diterimanya akan meningkat. Adapun faktor yang mempengaruhi dalam jalur utama ini antara lain; motivasi dan kemampuan individu dalam mengolah pesan. Pada jalur ini perubahan yang akan dihasilkan bersifat jangka panjang atau permanen.

- Jalur Periferal

Cacioppo and Petty dalam Littlejohn dan Foss (2009:331) mengatakan bahwa jalur periferal diperuntukkan bagi individu yang mengolah informasi yang diterimanya secara kurang kritis, serta keputusan yang dibuatnya tidak berdasarkan pesan itu sendiri. Pada jalur ini perubahan yang akan dihasilkan bersifat jangka pendek atau temporer.

\section{METODE PENELITIAN}

\section{Paradigma Penelitian}

Paradigma adalah basis kepercayaan utama atau metafisika dari sistem berpikir: basis dari ontology, epistemology, dan metodologi. Dalam pandangan filsafat, paradigma memuat pandangan-pandangan awal yang membedakan, memperjelas, dan mempertajam orientasi berpikir seseorang. Dengan demikian paradigma membawa konsekuensi praktis bagi perilaku, cara berpikir, interprestasi, dan kebijakan dalam pemilihan masalah. Paradigma memberikan representasi dasar yang sederhana dari suatu pandangan yang kompleks sehingga orang dapat memilih untuk bersikap atau mengambil keputusan (Salim, 2006:96).
Menurut Bogdan dan Biken dalam Moleong (2014:49) paradigma adalah kumpulan longgar dari sejumlah asumsi yang dipegang bersama, konsep atau proposisi yang mengarahkan cara berpikir dan penelitian. Paradigma merupakan pola atau model tentang bagaimana sesuatu distruktur (bagian dan hubungannya) atau bagaimana bagian-bagian berfungsi (perilaku yang didalamnya ada konteks khusus atau dimensi waktu).

Paradigma yang digunakan dalam penelitian ini adalah postpositivisme. Menurut Sugiyono (2016:8) filsafat postpositivisme sering juga disebut sebagai paradigma interpretif dan konstruktif, yang memandang realitas sosial sebagai sesuatu yang holistik/utuh, kompleks, dinamis, penuh makna, dan hubungan gejala bersifat interaktif (repiprocal). Penelitian dilakukan pada obyek yang alamiah. Obyek yang alamiah adalah obyek yang berkembang apa adanya, tidak dimanipulasi oleh peneliti dan kehadiran peneliti tidak mempengaruhi dinamika pada obyek tersebut.

\section{Tradisi Penelitian}

Tradisi penelitian yang digunakan peneliti dalam penelitian mengenai "Komunikasi Bisnis Berbasis Etika Lingkungan Sebagai Bentuk Corporate Social Responsibility The Body Shop Indonesia" adalah sosiopsikologis.

Disebutkan dalam Littlejohn (2009:63-64) kajian individu sebagai mahkluk sosial merupakan tujuan dari tradisi sosiopsikologis. Tradisi ini berfokus pada perilaku sosial individu, variabel psikologis, efek individu, kepribadian dan sifat, persepsi, serta kognisi. Banyak karya komunikasi terbaru dalam tradisi ini yang memperhatikan pada persuasi dan perubahan sikap, pemrosesan pesan, bagaimana individu merencanakan strategi pesan, bagaimana penerima pesan memproses informasi pesan, dan efek pesan pada individu.

Hal ini sejalan dengan penelitian yang sedang diteliti mengenai komunikasi bisnis beretika lingkungan yang dijalankan oleh The Body Shop Indonesia sebagai bentuk CSR melalui kampanye 
\#Pay4Plastic. Dimana kampanye tersebut mencoba mengedukasi serta mengubah perilaku masyarakat kearah positif. Disini peneliti melihat komunikasi bisnis yang dijalankan digunakan pula untuk mengubah perilaku masyarakat mengenai lingkungan sekitar. Jadi, tradisi sosiopsikologis yang digunakan bisa dijadikan peneliti sebagai tradisi penelitian yang berjalan pada penelitian ini.

\section{Pendekatan Penelitian}

Pendekatan penelitian yang digunakan adalah pendekatan kualitatif. Menurut Sugiyono (2014:8) metode penelitian kualitatif sering disebut metode penelitian naturalistik karena penelitiannya dilakukan pada kondisi yang alamiah (natural setting); disebut juga sebagai metode etnographi, karena pada awalnya metode ini lebih banyak digunakan untuk penelitian bidang antropologi budaya; disebut sebagai metode kualitatif, karena data yang terkumpul dan analisisnya lebih bersifat kualitatif.

Metode penelitian kualitatif adalah metode penelitian yang berlandaskan pada filsafat postpositivisme, digunakan untuk meneliti pada kondisi obyek yang alamiah, (sebagai lawannya adalah eksperimen) dimana peneliti adalah sebagai instrumen kunci, teknik pengumpulan data dilakukan secara triangulasi (gabungan), analisis data bersifat induktif/kualitatif, dan hasil penelitian kualitatif lebih menekankan makna dari pada generalisasi.

Pendekatan kualitatif yang digunakan oleh peneliti adalah secara metode deskriptif kualitatif. Menurut Nazir (2014:43) metode deskriptif adalah suatu metode dalam meneliti status sekelompok manusia, suatu objek, suatu set kondisi, suatu sistem pemikiran, ataupun suatu kelas peristiwa pada masa sekarang. Tujuan dari penelitian deskriptif ini adalah untuk membuat deskripsi, gambaran atau lukisan secara sistematis, faktual dan akurat mengenai fakta-fakta, sifat-sifat serta hubungan antarfenomena yang diselidiki.

\section{Unit Analisis}

Menurut Hamidi (2005:75-76) menyatakan bahwa unit analisis adalah satuan yang diteliti yang bisa berupa individu, kelompok, benda atau suatu latar peristiwa sosial seperti misalnya aktivitas individu atau kelompok sebagai subjek penelitian.

Dari cara mengungkap unit analisis data dengan menetapkan kriteria responden tersebut, peneliti dengan sendirinya akan memperoleh siapa dan apa yang menjadi subjek penleitiannya. Dalam hal ini peneliti akan mencoba menemukan informan awal yakni orang yang pertama memberi informasi yang memadai ketika peneliti mengawali aktivitas pengumpulan data. Adapun yang menjadi unit analisis data penelitian ini adalah individu sebagai stakeholders di The Body Shop.

\section{Teknik Pengumpulan Data}

Dalam teknik pengumpulan data, peneliti menggunakan teknik-teknik yang Yin jelaskan dalam bukunya, "Studi Kasus (Desain \& Metode)" (2015:101). Bukti atau data untuk keperluan studi kasus bisa berasal dari enam sumber, yaitu: dokumen, rekaman arsip, wawancara, pengamatan langsung, observasi partisipan, dan perangkatperangkat fisik.

\section{Uji Keabsahan Data}

Dalam penelitian ini uji keabsahan data menggunakan analisis Triangulasi, yaitu menganalisis jawaban subjek dengan meneliti kebenaran dengan data empiris atau sumber data lain yang tersedia. Di sini jawaban dari subjek di cross-check dengan dokumen yang ada.

\section{HASIL DAN PEMBAHASAN}

The Body Shop Indonesia merupakan salah satu perusahaan kosmetik asal Inggris yang masuk ke Indonesia melalui sistem franchise yang dibawa oleh Suzy Hutomo. Keberadaan The Body Shop sendiri di dunia kosmetik kecantikan pada tahun 2016 menginjak tahun ke-40. Sedangkan untuk di Indonesia sendiri The Body Shop memasuki tahun ke-24 pada 
Desember 2016 lalu. The Body Shop tergolong bisnis retail yang sudah menjadi bagian dari Grup L'Oréal. Namun yang menjadi unique selling point dalam bisnis yang dimilikinya adalah keteguhan statement yang dibuat oleh Anita Roddick sang pendiri The Body Shop. Bisnis yang dijalankannya memiliki perbedaan diandingkan dengan bisnis lainnya. Hal yang membedakannya adalah bisnis yang dijalankan merupakan bisnis yang beretika serta bertanggung jawab.

Etika dan tanggung jawab adalah dua hal yang saling melengkapi satu sama lain dalam sebuah bisnis yang dijalankan oleh Anita Roddick. Mengaku bisnis yang dimilikinya berbeda dengan yang lain, The Body Shop setiap tahunnya selalu mengeluarkan values report mengenai prinsip bisnis serta apa saja yang telah dicapai dan fokus apa saja yang akan dilakukan untuk tahun-tahun berikutnya. Dalam values report yang dipublikasikan secara terbuka, peneliti menemukan inti dari bisnis The Body Shop yang selalu diulang dan diutarakan dalam setiap laporan yang mereka publikasikan. The Body Shop selalu mengutarakan dalam values report yang dibuat mengenai The Body Shop merupakan pelopor CSR serta bisnis global pertama yang mempraktikkan perdagangan yang adil serta melakukan kampanye sosial dan lingkungan. Selain itu dalam values report yang dipublikasikan juga selalu diutarakan mengenai The Body Shop sebagai brand kosmetik yang paling beretika di dunia dan bisnis global berkelanjutan yang sebenarnya. Mengenai hal tersebut juga sering sekali di ulas peneliti sebelumnya terkait dengan fakta-fakta yang peneliti temukan di lapangan.

Peneliti melihat bahwa adanya keteguhan serta komitmen dari waktu ke waktu yang tidak berubah. Namun komitmen tersebut menjadi kuat pada saat The Body Shop memasuki angka ke-40 tahun lalu. Sejak The Body Shop didirikan hingga 2015, mereka menggunakan 5 core values, yaitu: Activate Self Esteem, Against Animal Testing, Defend Human Rights, Protect Our Planet and Support Community Fair Trade. Hal tersebutlah yang menjadi pedoman The Body Shop secara internasional dalam melakukan komunikasi bisnisnya sehari-hari, baik dengan karyawan, distributor, konsumen, bahkan masyarakat sekitar. Walaupun The Body Shop memiliki sistem franchise \& telah menjadi bagian dari Grup L'Oréal, namun 5 core values yang dimilikinya tetaplah sama dan digunakan dalam setiap level komunikasi bisnis yang dilakukannya. Memasuki usia ke-40 pada Februari 2016 lalu, 5 core values yang dimiliki The Body Shop bertransformasi menjadi komitmen bisnis yang semakin fokus dan kuat dengan tema Enrich Not Exploit (It's In Our Hands). Sesuai dengan namanya yang berarti untuk memperkaya bisnis tidak harus dengan cara mengeksploitasi dan hal tersebut bisa dimulai dengan tangan kita sendiri. Komitmen bisnis yang baru semakin fokus dengan memiliki 3 agenda penting yang harus dicapai oleh The Body Shop International di tahun 2020, yaitu: Enrich Our Planet, Enrich Our People, Enrich Our Product. The Body Shop Indonesia sendiri membantu tercapainya komitmen tersebut melakukan agenda kegiatan yang sifatnya internasional dan lokal.

Komunikasi bisnis yang dilakukan oleh The Body Shop mengedepankan unsur etika dan tanggung jawab. Peneliti melihat ada kaitannya dengan dua hal tersebutlah, yaitu: Etika dan Tanggung Jawab yang membangun setiap elemen bisnis yang dilakukan oleh The Body Shop. Mulai dari komunikasi berbisnis hingga kegiatan CSR yang dilakukannya, berpedoman pada dua unsur tersebut yang dikukuhkan melalui sebuah prinsip bisnis Enrich Not Exploit (It's In Our Hands). Etika yang digunakan dalam kegiatan berbisnis The Body Shop lebih banyak terkait dengan isu-isu yang melibatkan persoalan sosial dan lingkungan. Sehingga komunikasi bisnis yang dibangun adalah mengenai hal tersebut.

Seperti yang telah diulas sebelumnya, bahwa komunikasi bisnis serta prinsip bisnis yang dijalankan mengandung unsur etika \& tanggung jawab, maka hal tersebut tentunya perlu dikomunikasikan kepada para stakeholder yang menjadi bagian dari roda bisnis The Body Shop. 
Menurut hasil yang peneliti temukan di lapangan baik melalui hasil wawancara dengan para narasumber serta dicocokan dengan dokumentasi-dokumentasi terkait hasil wawancara, peneliti mendapati The Body Shop Indonesia menggunakan kanalkanal komunikasi yang dimiliki sebagai media penyampai kebijakan serta komunikasi The Body Shop Indonesia yang bersifat dari atas ke bawah. Hal tersebut terlihat dalam strategi produk yang dimiliki oleh The Body Shop. Disetiap jejaring sosial, store, paper bag, values report, head office dan media lainnya selalu diinfokan mengenai prinsip bisnis seperti apa yang dijalankan oleh The Body Shop. Untuk bukti-bukti tersebut, peneliti cantumkan dalam hasil temuan penelitian.

Cara komunikasi bisnis yang dilakukan menurut peneliti tergolong sangat visioner, dimana The Body Shop Indonesia khususnya menggunakan media strategi produk serta PR dalam proses mepublikasikan prinsip bisnis yang dijalankan. Dengan cara tersebut prinsip bisnis Enrich Not Exploit yang dimiliki dan dijalankan oleh The Body Shop bisa diketahui oleh seluruh pihak yang terkena paparan dari informasi tersebut.

Dari prinsip bisnis yang dijalankan oleh The Body Shop yang fokus dalam dua hal, yaitu: etika dan tanggung jawab serta hal-hal yang bersifat sosial dan lingkungan menjadi suatu pondasi kegiatan serta strategi marketing yang dilakukan. Strategi yang dilakukan tentunya harus berdasarkan prinsip bisnis yang sudah dikukuhkan bersama. Dalam hal ini kehadiran sebuah prinsip bisnis memiliki posisi yang sangat penting akan keberlangsungan kegiatan dalam roda bisnis The Body Shop Indonesia khususnya. Di Indonesia sendiri, The Body Shop memainkan strategi pemasaran serta CSR dalam ranah sosial dan lingkungan dengan tetap mengedepankan etika serta tanggung jawab dalam melakukan bisnisnya.

Salah satu kegiatan komunikasi bisnis berbasis etika lingkungan yang dijalankan oleh The Body Shop Indonesia berupa CSR melalui Kampanye \#Pay4Plastic. Peneliti melihat dikarenakan ini masuk dalam salah satu kegiatan komunikasi bisnis serta The Body Shop Indonesia merupakan perusahaan retail, di mana pasti mengharapkan profit dalam bentuk kegiatan yang dijalankannya. Peneliti juga melihat bentuk profit yang hendak dicapai adalah dari para konsumen serta karyawan yang memiliki sikap loyalitas akan produk The Body Shop, bukan konsumen atau karyawan yang hanya tertarik akan produk tersebut sesaat dan membelinya hanya sesekali saja.

Berdasarkan hasil wawancara yang dilakukan oleh peneliti, Rika Anggraini selaku GM Corporate Communication The Body Shop Indonesia mengatakan bahwa CSR dilakukan untuk menciptakan konsumen dan karyawan yang loyalitas akan produk The Body Shop. Jadi, CSR melalui Kampanye \#Pay4Plastic tidak hanya sekedar sebuah kampanye yang memberikan edukasi kepada masyarakat serta membantu organisasi non profit yang bergerak di bidang lingkungan untuk menghasilkan sebuah proses atau kebijakan yang berdampak positif. Namun, CSR dan kampanye tersebut dijadikan sebuah strategi pemasaran yang dilakukan oleh The Body Shop Indonesia dalam menciptakan profit jangka panjang serta loyalitas terhadap konsumen dan karyawan.

Peneliti melihat aktivitas CSR yang dilakukan melalui Kampanye \#Pay4Plastic sesuai dengan piramida bisnis yang dimiliki, yaitu Planet, People, dan Profit. Dimana kegiatan yang dilakukan dalam roda bisnis yang dijalankan harus tetap menjaga kelestarian lingkungan. Hal tersebut sesuai dengan CSR yang dilakukan melalui Kampanye \#Pay4Plastic, dimana The Body Shop Indonesia mengedukasi masyarakat serta mengajak masyarakat untuk sama-sama melakukan aksi pengurangan kantong plastik serta penandatangan petisi plastik berbayar. Dengan melibatkan partisipasi para karyawan \& konsumen The Body Shop Indonesia, serta masyarakat yang terkena paparan informasi tersebut diharapkan dapat menciptakan para agent of change untuk keberlangsungan lingkungan hidup. Selain hal tersebut yang ingin diciptakan adalah konsumen dan karyawan loyalitas yang bisa 
menghasilkan profit jangka panjang bagi The Body Shop Indonesia.

Peneliti menilai komunikasi bisnis

yang dijalankan berdasarkan etika lingkungan melalui sebuah program CSR, yaitu Kampanye \#Pay4Plastic, tidak hanya sebuah CSR biasa yang dilakukan pada umumnya, namun hal ini merupakan strategi bisnis yang dijalankan oleh The Body Shop. Strategi yang dijlankan seperti soft selling yang bertujuan menghasilkan sebuah penjualan dari konsumen yang memiliki loyalitas terhadap produk The Body Shop. Ketika konsumen \& karyawan tersebut loyal akan sebuah produk, maka mereka dengan senantiasa mendukung apa yang dilakukan oleh suatu produk \& korporasinya. Terkait hal ini seorang pelanggan yang loyal tidak akan melihat sisi harga yang dibandrol oleh produk tersebut, namun lebih melihat terhadap apa yang dilakukan oleh produk tersebut dan apa yang bisa pelanggan lakukan untuk mendukung kegiatan yang dilakukan. Hal inilah yang dibangun oleh The Body Shop melalui komunikasi bisnis yang dijalankan dengan menggunakan konsep CSR. Tidak hanya memperkuat identitas merek, tetapi juga dapat menciptakan konsumen serta karyawan yang memiliki sikap loyalitas terhadap The Body Shop. Sehingga bisnis The Body Shop Indonesia bisa berkelanjutan dalam ranah bisnis kosmetik di Indonesia.

\section{SIMPULAN DAN SARAN}

\section{Simpulan}

Berdasarkan hasil wawancara, observasi, dan dokumentasi mendalam mengenai komunikasi bisnis berbasis etika lingkungan sebagai bentuk CSR The Body Shop Indonesia (Studi Kasus: Kampanye \#Pay4Plastic The Body Shop Indonesia di Jakarta), peneliti menyimpulkan bahwa:

1. The Body Shop melakukan komunikasi bisnisnya secara lingkup internal \& eksternal korporasi dengan menggunakan kanal-kanal komunikasi yang digunakannya. Adapun kanal komunikasi yang digunakan untuk menyampaikan prinsip bisnis yang dijalankannya adalah: Strategi komunikasi produk, Public Relations, serta sudut-sudut yang berada di Head Office The Body Shop Indonesia yang dijadikan sebagai penggambaran jenis bisnis yang dijalankan oleh The Body Shop Indonesia khususnya.

2. The Body Shop fokus akan hal-hal yang bersifat sosial dan lingkungan dikarenakan tujuan The Body Shop adalah sebagai brand kosmetik yang paling beretika di dunia dan bisnis global berkelanjutan yang sebenarnya. Selain itu, The Body Shop merupakan pelopor CSR serta bisnis global pertama yang mempraktikkan perdagangan yang adil serta melakukan kampanye sosial dan lingkungan. Hal inilah yang membuat The Body Shop fokus terhadap isu-isu yang mengangkat ranah sosial dan lingkungan. CSR yang dilakukan The Body Shop Indonesia melalui Kampanye \#Pay4Plastic juga terkait dengan hal tersebut, dimana kampanye yang dilakukan selain untuk membangun kesadaran masyarakat akan sampah plastik. Kampanye tersebut juga digunakan sebagai komunikasi bisnis untuk menciptakan para karyawan dan konsumen yang loyalitas.

3. The Body Shop melihat dampak positif yang ditimbulkan dari Kampanye \#Pay4Plastic ini melalui banyaknya publik yang ikut terlibat dalam pengumpulan petisi plastik berbayar. The Body Shop Indonesia juga melihat dari sisi tindak lanjut dari kampanye \#Pay4Plastik yang telah ditanggapi oleh KLHK pada tanggal 30 Desember 2015 akan petisi yang telah dikumpulkan oleh The Body Shop Indonesia secara offline. Hasil dari petisi tersebut dengan dikeluarkannya surat edaran di bawah Dirjen Pengelolaan Sampah, Limbah, dan Bahan Beracun Berbahaya (Nomor: SE06/PSLB3-PS/2015) yang ditujukan kepada kepala daerah dan pelaku 
usaha; mengenai penerapan plastik berbayar di seluruh gerai pasar modern di Indonesia.

\section{Saran}

Penelitian mengenai komunikasi bisnis berbasis etika lingkungan dapat dikembangkan lebih lanjut karena bersifat dinamis. Hal ini mendorong berkembangnya disiplin dan konsep komunikasi bisnis. Penulis menyarankan untuk menggunakan berbagai metodologi studi kasus dari berbagai pakar, seperti Robert K. Yin, dengan berbagai pendekatan komunikasi bisnis yang telah banyak berkembang di dunia bisnis, seperti social marketing.

Komunikasi bisnis berbasis etika lingkungan yang dilakukan oleh The Body Shop Indonesia sebagai bentuk CSR-nya melalui Kampanye \#Pay4Plastic sudah bagus. Peneliti melihat hal ini selalu dilakukan secara konsisten oleh The Body Shop Indonesia guna mengedukasi serta mengajak para karyawan, konsumen dan masyarakat umumnya untuk bersama-sama melakukan kegiatan bisnis yang bertanggung jawab. Dimana dalam melakukan kegiatan kita sehari-hari, kita juga harus selalu senantiasa menjaga lingkungan sekitar.

Peneliti menyarankan agar kegiatan

Kampanye \#Pay4Plastic tetap terus dilakukan secara konsisten. Namun pelaksanaannya ada baiknya dilakukan juga dibeberapa titik yang dirasa masih memiliki tingkat penggunaan kantong plastik yang tinggi, seperti: pasar tradisional, pasar modern, dan sebagainya. Selain itu dengan Program Bag For Life yang berada di Store The Body Shop Indonesia, agar setiap staff store yang berada dilokasi untuk ikut serta mengedukasi serta menawarkan reusable bag tersebut, agar para konsumen dan pengunjung bisa membeli serta menggunakannya dan bisa ikut serta dalam pengurangan penggunaan kantong plastik.

\section{DAFTAR PUSTAKA}

Alifahmi, Hifni. 2005. Sinergi Komunikasi Pemasaran: Integrasi Iklan, Public Relations, dan Promosi. Quantum, Jakarta.

Annual Report Gerakan Indonesia Diet Kantong Plastik tahun 2015, diunduh pada tanggal 22 Oktober 2016.

Annual Report Gerakan Indonesia Diet Kantong Plastik Tahun 2015.

Annual Review The Body Shop Foundation Tahun 2015.

Ardianto Elvinaro-Dindin M.Machdudz, 2011. Efek Kedermawanan Pebisnis dan CSR. Gramedia, Jakarta.

Bungin, Burhan. 2006. Sosiologi Komunikasi: Teori, Paradigma, dan Diskusi Teknologi Komunikasi di Masyarakat. Kencana Prenada Media Group, Jakarta.

Clow, Kenneth E., dan Baack, Donald. 2007. Integrated Advertising, Promotion, and Marketing Communications.Pearson Practice Hall, New Jersey.

Cresswell, John W. 2010. Research Design: Pendekatan Kualitatif, Kuantitatif, dan Mix. Pustaka Pelajar, Yogyakarta.

Griffin, EM. 2006, A First Look At Comunication Theory. Mc Graw Hill, Singapore.

Hamidi. 2005. Metode Penelitian Kualitatif: Aplikasi Praktis Pembuatan Proposal dan Laporan Penelitian. UMM PRESS, Malang.

Hardiman, Ima. 2006. 400 Istilah PR Media \& Periklanan, Gagas Ulung, Jakarta. 
Jefkins, Frank. 2003. Public Relations, Erlangga, Jakarta.

Katz, Bernard. 1994. Turning Practical Communication into Business Power. (Terjemahan). PT. Pustaka Binaman Pressindo, Jakarta.

Kotler Philip-Nancy Lee. 2005. Corporate Social Responsibility. John Welly and Sons, New Jersey.

Kotler Philip - Gary Armstrong. 2012. Prinsip-Prinsip Pemasaran. Edisi13. Jilid 1. Erlangga, Jakarta.

Kotler Philip - Kevin Lane Keller. 2012. Marketing Management 13. Pearson Prentice Hall, Inc, New Jersey.

Kriyantono, Rachmat. 2006. Teknik Praktis Riset Komunikasi. Kencana, Jakarta.

2009. Teknik Praktis Riset Komunikasi. Kencana, Jakarta.

2012. Teknik Praktis Riset Komunikasi. Jakarta: Kencana.

Larson, Charles U. 1992. Persuasion; Reception and

Responsibility.Wadsworth

Publishing Company, California.

Littlejohn, Stephen W., dan Foss, Karen A. 2009. Encyclopedia of Communication Theory. Sage Publications, California.

Levy SJ, Zaltman G. 1975. Marketing, society and conflict. Englewood Cliffs. Prentice Hall, New Jersey.

Ma'ruf, M Abdullah. 2015. Manajemen Komunikasi Korporasi. Aswaja Pressindo, Yogyakarta.

Moleong, Lexy. 2014. Metodologi Penelitian Kualitatif. Remaja Rosda Karya, Bandung.
Mulyana, Deddy. 2002. Metodologi Penelitian Kualitatif. Bandung: Remaja Rosda Karya.

2008. Ilmu Komunikasi Suatu Pengantar. PT Remaja Rosdakarya, Bandung.

2012. Ilmu Komunikasi Suatu Pengantar. Remaja Rosda Karya, Bandung.

Nazir, Moh. 2014. Metode Penelitian. Ghalia Indonesia, Bogor.

Nindita, Maria. 2014. Sustainable Business \& Corporate Social Responsibility. CECT, Jakarta.

Nova, Firsan. 2009. Crisis Public Relations, PT Grasindo, Jakarta.

Oepen Manfred - Winfried Hamacher. 1999. Environmental Communication for Sustainable Development. Universum Verlagsanstalt, Wiesbaden.

Ostergaard, Leon. 2002. Effective Campaign Assessment: How To Learn From Your Failures.

Hans-Dieter Klingemann \& Andrea Roemmele. 2002. Public Information Campaign \& Opinion Research. Sage Publications, Thousand Oaks.

Poerwanto dan Zakaria Lantang Sukirno. 2012. Komunikasi Bisnis: Perspektif Konseptual dan Kultural. Pustaka Pelajar, Yogyakarta.

Purwanto, Djoko. 2006. Komunikasi Bisnis. Erlangga, Jakarta.

Riant, Nugroho D. 2004. Kebijakan Publik: Formulasi, Implementasi dan Evaluasi. PT. Elex Media Komputindo, Jakarta. 
Roddick, Anita. 2013. Business As Unusual. Kompas Gramedia, Jakarta.

Ruslan, Rosady. 2003. Metode Penelitian $P R$ dan Komunikasi. PT Rajagrafindo Persada, Jakarta. Relations. PT Rajagrafindo Persada, Jakarta.

Salim, Agus. 2006. Teori dan Paradigma Penelitian Sosial: Edisi Kedua. Tiara Wacana, Yogyakarta.

Shimp, A, Terrence. 2003. Periklanan Promosi Aspek Tambahan Komunikasi Pemasaran Terpadu. PT Erlangga, Jakarta.

Soekanto, Soerjono. 2012. Sosiologi Suatu Pengantar. Rajawali Press, Jakarta.

Soemirat,Soleh., dan Savitri Hidayat. 2004. Komunikasi Persuasif. Pusat Penerbitan Universitas Terbuka, Jakarta.

Sonny, A Keraf. 2010. Etika Bisnis: Tuntutan dan Relevansinya. Kanisius, Yogyakarta.

Sugiyono. 2016. Metode Penelitian Kuantitatif, Kualitatif dan $R \& D$. Alfabeta, Bandung.

Sunyoto Danang \& Harisa Wika. 2016. Etika Bisnis: Membangun Kesuksesan Bisnis Melalui Manajemen dan Perilaku Bisnis yang Beretika. CAPS, Yogyakarta.

The Body Shop International PLC Value Report Tahun 2011
The Body Shop International PLC Value Report Tahun 2014/2015

The Body Shop International PLC Value Report Tahun 2011-2013

Venus, Antar. 2009. Manajemen Kampanye, Simbiosa Rekatama Media, Bandung.

West, Richard dan Turner, Lynn H. 2008. Pengantar Teori Komunikasi: Analisis dan Aplikasi. Salemba Humanika, Jakarta.

www.dietkantongplastik.info, diunduh pada tanggal 31 Oktober 2016

http://www.cnnindonesia.com/gayahidup/20160222182308-277112685/indonesia-penyumbangsampah-plastik-terbesar-ke-duadunia/, diunduh pada tanggal 27 Desember 2016

http://www.thebodyshopusa.com/values/ProtectPlanet.aspx , diunduh pada tanggal 23 Februari 2017

http://lifestyle.liputan6.com/read/2387851/th e-body-shop-dukung-perjuanganham-di-indonesia, diunduh pada tanggal 23 Februari 2017

http://nasional.kompas.com/read/2013/03/19 /21032734/the.body.shop.ajak.kuran gi.sampah.plastik., diunduh pada tanggal 23 Februari 2017

Zulrizka Iskandar, Tb. 2012. Psikologi Lingkungan: Teori dan Konsep. Refika Aditama, Bandung. 